\title{
ВИБІР ТАКТИКИ ЛІКУВАННЯ КАЛЬЦИФІКУЮЧОГО ТЕНДИНІТУ ПЛЕЧА 3 УРАХУВАННЯМ ФАЗИ ПЕРЕБІГУ ЗАХВОРЮВАННЯ
}

\section{Вибір тактики лікування кальцифікуючого тендиніту плеча з урахуванням фази перебігу захворювання}

\section{Ю. О. Грубар ${ }^{1}$, М. Ю. Грубар ${ }^{2}$}

Тернопільський національний медичний університет імені І. Я. Горбачевського МОЗ України ${ }^{1}$

КНП «Тернопільська університетська лікарня» TOP 2

Резюме. Кальцифрікуючий тендиніт є доволі поширеним захворюванням плечового суглоба з характерним накопиченням гідроксиапатиту кальцію в сухожиллях обертової манжети та супроводжується больовим синдромом і фукциіональним розладами в суглобі.

Мета дослідження - на основі клінічних проявів та результатів додаткових методів дослідження сорормувати методику індивідуального підходу в виборі лікувальної тактики даного захворювання та провести оцінку результатів.

Матеріали і методи. Проведено обстеження та лікування 74 пацієнтів із кальцифрікуючим тендинітом сухожилків обертальної манжети плеча. Середній вік пацієнтів становив $(45,4 \pm 1,3)$ року, чоловіків було 28 (37,84 \%), жінок - 46 (62,16 \%). Обстеження включало: загальноклінічні та інструментальні методи дослідження, а саме - огляд пацієнта з проведенням фрункціональних тестів для плечового суглоба, рентгенографрію, сонографрію, при показаннях - магнітно-резонансну томографрію.

Результати. Лікування підбиралося максимально індивідуально для кожного пацієнта з урахуванням фрази перебігу захворювання. У 33 (62,27 \%) осіб через 2 тижні з моменту лікування відмічалося клінічне та сонографрічне одужання. Оперативне лікування під артроскопічним контролем проведено 10 (13,51 \%) пацієнтам.

Висновки. Лікування повинно бути підібрано максимально індивідуально для кожного пацієнта з урахуванням фразовості перебігу захворювання та включати нестероїдні протизапальні препарати, небензодіазепінові спазмолітики, нідліне із використанням місцевих анестетиків та пролонгованих глюкокортикоїдів, кріотерапію та лікувальну фрізкультуру.

Ключові слова: плечовий суглоб; кальцифрікуючий тендиніт; обертальна манжета плеча; рентгенограсрія; сонографрія; магнітно-резонансна томографрія; нідлінг.
Tactics choice of treatment of shoulder calcific tendinitis taking into account the phase of the disease

Yu. O. Hrubar' ${ }^{1}$ M. Yu. Hrubar ${ }^{2}$

I. Horbachevsky Ternopil National Medical University ${ }^{1}$ Ternopil University Hospital ${ }^{2}$

e-mail: hrubar@ukr.net

Summary. Calcific tendinitis is a fairly common disease of the shoulder joint with a characteristic accumulation of calcium hydroxyapatite in the tendons of the rotator cuff. This disease is accompanied by pain and functional disorders in the shoulder joint.

The aim of the study - to form a method of individual approach in the choice of treatment tactics of this disease on the basis of clinical manifestations and results of additional research methods and to evaluate the results.

Materials and Methods. Examination and treatment of 74 patients with calcific tendonitis of the rotator cuff were performed. The mean age of patients

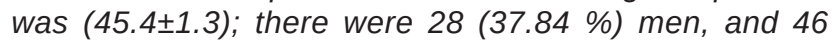
(62.16 \%) women. The examination included: general clinical and instrumental methods of study, namely -examination of the patient with functional tests for the shoulder joint, radiography, sonography, with indications - magnetic resonance imaging.

Results. Treatment was selected as individually as possible for each patient taking into account phases of the disease. Clinical and sonographic recovery was noted in $33(62.27 \%)$ people in 2 weeks after treatment. Surgical treatment under arthroscopic control was performed in 10 (13.51\%) patients.

Conclusions. Treatment should be selected individually for each patient, taking into account the phase of the disease and include non-steroidal anti-inflammatory drugs, non-benzodiazepine antispasmodics, needling with local anesthetics and prolonged glucocorticoids, cryotherapy and physical therapy.

Key words: shoulder joint; calcific tendinitis; rotator cuff; radiography; sonography; MRI; needling. 


\section{ВСТУП}

Патологія обертальної манжети плеча включає широкий спектр захворювань, серед яких помітну роль відіграє кальцифрікуючий тендиніт. Кальцифрікуючий тендиніт плеча - це гостре або хронічне захворювання плечового суглоба, викликане відкладенням кристалів гідроксиапатиту кальцію, зазвичай в сухожилля надостьового та підостьового м'язів [13].

На сьогодні етіологія кальцифрікуючого тендиніту до кінця не вияснена. Дві найбільш відомі етіологічні теорії - це дегенеративна теорія, запропонована H. Refior et al. [10], у якій підкреслюється схожість даної патології з дегенеративними ураженнями обертальної манжети плеча, і теорія багатофразного перебігу захворювання, запропонована H. Uhthoff, J. Loehr [14], в якій перебіг захворювання передбачає як відкладення кальцію в тканинах, так $\mathrm{i}$ спонтанну його резорбцію.

Згідно з матеріалами досліджень, поширеність кальцифрікуючого тендиніту в дорослих коливається від 2,7 до $20 \%[5,4]$. Найчастіше дана патологія проявляється у віці 40-60 років і $є$ двосторонньою у 10-25\% пацієнтів [14]. Захворювання частіше буває у жінок, в яких воно виникає вдвічі частіше, ніж у чоловіків [1]. Факторами ризику для розвитку даного патологічного стану вважаються профресії, які вимагають тривалого утримання верхньої кінцівки в положенні внутрішньої ротації і незначного відведення плеча (касири, кравці, працівники конвеєрних ліній, електрики). Хоча було запропоновано доволі багато методів лікування, на сьогодні оптимальний варіант вибору залишається спірним $[9,11]$.

Метою дослідження було на основі клінічних проявів та результатів додаткових методів дослідження сорормувати методику індивідуального підходу в виборі лікувальної тактики при кальцифікуючому тендиніті плеча та провести оцінку результатів.

\section{МАТЕРІАЛИ I МЕТОДИ}

В ортопедично-травматологічному відділення КНП «Тернопільська університетська лікарня» ТОР за період з 2013 до 2021 р. проведено обстеження та лікування 362 пацієнтів із патологією плечового суглоба, серед яких 74 (20,38 \%) були з кальцифікуючим тендинітом сухожилків обертальної манжети плеча. Середній вік пацієнтів становив $(45,4 \pm 1,3)$ року, чоловіків було 28 (37,84 \%), жінок - $46(62,16$ \%). У 45 (60,82 \%) осіб патологічний процес виник у правому плечовому суглобі, в 22 (29,73 \%) - в лівому плечі. В 7 (9,45 \%) пацієнтів у процесі обстеження патологію виявлено в обох суглобах.

Обстеження хворих включало: загальноклінічні та інструментальні методи дослідження, а саме - огляд пацієнта з проведенням фрункціональних тестів для плечового суглоба, рентгенографрію, сонографрію, при показаннях - магнітно-резонансну томо- грасрію. При клінічному обстеженні приділяли увагу характеристиці больового синдрому його інтенсивності та локалізації. Одночасно проводили рентгенологічне дослідження плечового суглоба в двох проекціях (передньо-задня та осьова Ү-проекція). Усім пацієнтам проводилося сонографрічне дослідження апаратом Acuson Antares (Siemens) з використанням високочастотного широкосмугового датчика з робочою частотою 7-12 МГц. У 15 осіб було виконано MPT суглоба на магнітно-резонансному томографі «Philips Achieva 1.5T». Для цього обстеження використали послідовності T2W ax (TR/TE 3357/30), T1W cor (TR/TE 2376/30) та PDW VISTA (TR/TE 1300/31). Товщина зрізів витримана в межах 3-3,5 мм. Оцінку больового синдрому проводили за шкалою ВАШ [7]. 3 метою визначення функції плечового суглоба до та після проведеного лікування застосовували шкалу Constant [2].

\section{РЕЗУЛЬТАТИ Й ОБГОВОРЕННЯ}

Залежно від тривалості симптомів та фразовості захворювання ми визначили 29 (39,19 \%) пацієнтів, які мали хронічний перебіг патології. Підгострий перебіг діагностовано у 33 (44,60 \%) хворих, із гострим перебігом захворювання звернулося 12 (16,21 \%) пацієнтів [4]. Середній розвиток симптомів становив $(9,0 \pm 1,91)$ місяця.

Серед провідних симптомів при кальцифрікуючому тендиніті виявився больовий синдром. На біль, що локалізувався по передній поверхні плечового суглоба, скаржилося 8 (10,82 \%) пацієнтів, по бічній поверхні верхньої третини плеча - 31 (41,89 \%) хворий. Біль локалізований по задній поверхні плечового суглоба відзначали 6 (8,10 \%) пацієнтів. На нелокалізований біль скаржилося 14 (18,92 \%) осіб. Іррадіацію болю в лопатку відмітили 6 (8,10 \%) хворих, в бічну поверхню шиї - $9(12,17 \%)$ пацієнтів (рис. 1).

Оцінку больового синдрому проводили за шкалою ВАШ [7]. Під час обстеження при хронічному перебігу захворювання середні показники інтенсивності болю пацієнти оцінювали в $(3,87 \pm 0,42)$ бала за шкалою ВАШ із суб'єктивною його характеристикою як періодичний, слабкий, тупий, ниючого характеру. 3 підгострим перебігом біль був більш вираженим та становив $(5,84 \pm 0,21)$ бала за шкалою ВАШ. Пацієнти його характеризували як тиснучий, позпираючий та викручуючий, що носить практично постійний характер, та посилюється в нічний час. При гострому перебігу пацієнти визначали біль у $(7,81 \pm 0,23)$ бала за шкалою ВАШ, даючи йому наступну характеристику: гострий, пульсуючий, свердлячий, що інколи доводить до відчаю, особливо інтенсивний у нічний час та такий, що не давав змоги лежати на боці ураження.

Проводячи аналіз рентгенограм, ми виявили три типи відкладень гідроксиапатиту кальцію в 


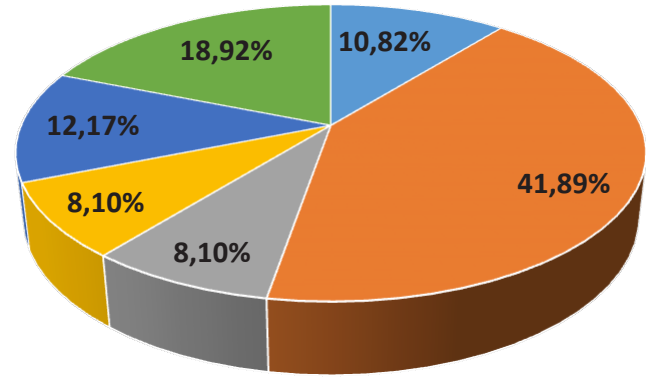

\section{- передня поверхня плеча \\ - задня поверхня плеча \\ - бічна поверхня шиї}

\author{
- бічна поверхня в/3 плеча \\ - лопатка \\ " не локалізований біль
}

Рис. 1. Локалізація болю в ділянці плечового суглоба при кальцифікуючому тендиніті.

обертальну манжету плеча. I тип - сформовані, щільні кальцинати з чіткою межею - у 20 (27,03 \%) пацієнтів, II тип - 3 чіткою межею та неоднорідною структурою - 41 (55,41 \%) хворий. Третій тип кальцинатів без чіткої межі з напівпрозорою структурою виявлено у 13 (17,56 \%) пацієнтів [6] (рис. 2).

Згідно з результатами сонограсрічних обстежень під час сонографії виявлено наступні типи відкладень гідроксиапатиту кальцію. Перший тип характеризувався гіперехогенним вогнищем з чітко визначеною ультразвуковою доріжкою 22 (29,73\%) пацієнтів. При другому типі кальцифрікація визначалася як гіперехогенне вогнище 3 пониженою ультразвуковою доріжкою - 38 (51,35 \%) хворих. При третьому типі кальцинати виглядали як вогнище 3 дещо зниженою гіперехогенністю без ультразвукової доріжки - 14 (18,92 \%) випадків (рис. 3) [3].

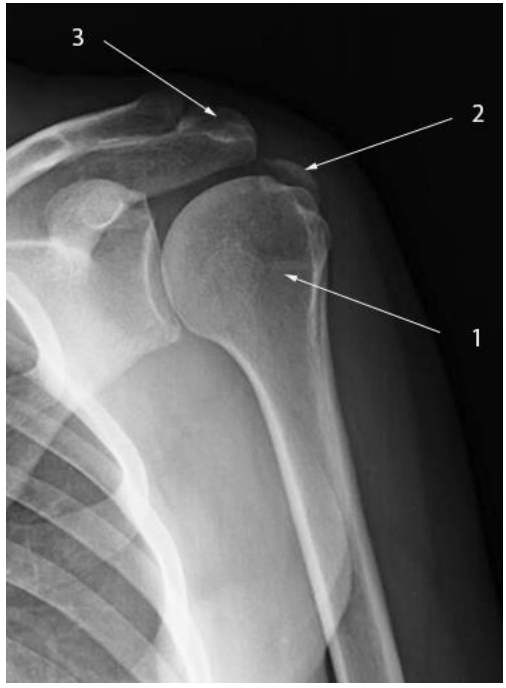

A

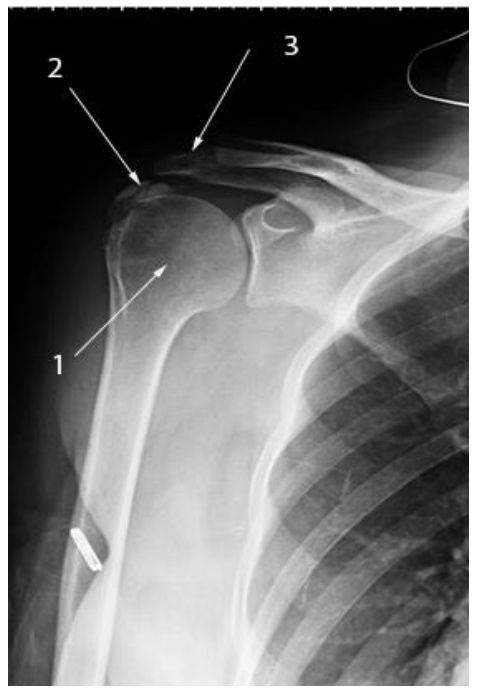

B
МРТ плечового суглоба провадили з метою диференційної діагностики $з$ адгезивним капсулітом та дегенеративним розривом обертальної манжети плеча (рис. 4).

Вибір лікувальної тактики ми визначили за наступними показниками: терміном клінічних проявів захворювання, вираженням больового синдрому, фрукціональними розладами в плечовому суглобі та результатами додаткових методів дослідження, що власне вказувала на характер перебігу захворювання. На основі отриманих результатів пацієнтів поділили на три групи: пацієнти з хронічним перебігом захворювання, підгострим та гострим перебігом кальцифрікуючого тендиніту плеча.

У хворих при хронічному перебігу больовий синдром за шкалою ВАШ не первищував 2,5 бала, фукціональні розлади в плечовому суглобі становили в середньому 71,86 бала за шкалою Constant.

Рис. 2. Типи відкладень гідроксиапатиту кальцію в обертальну манжету плеча: А. I тип - сформовані, щільні кальцинати з чіткою межею; B. II тип - 3 чіткою межею та неоднорідною структурою; C. III тип - без чіткої межі з напівпрозорою структурою.

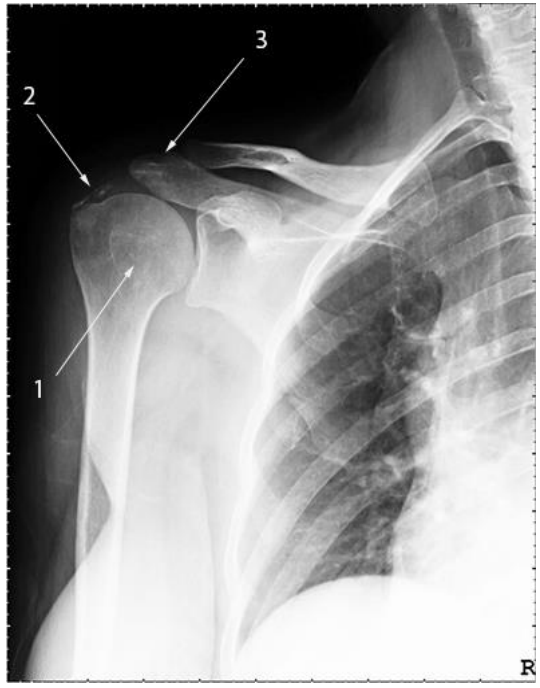

C . 


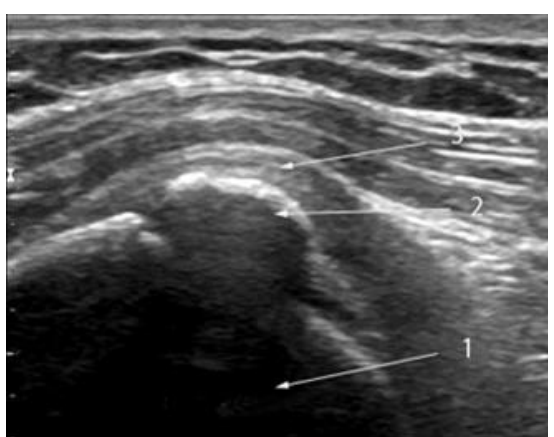

A

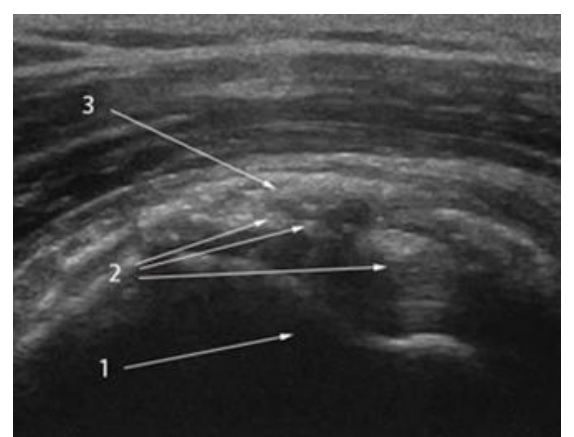

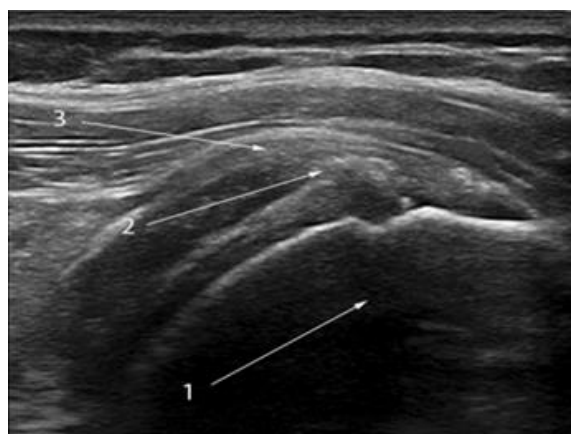

C

Рис. 3. Сонографрічні типи кальцифрікуючого тендинозу плеча: А. I - тип характеризується гіперехогенним вогнищем із чітко визначеною ультразвуковою тінню (1 - ультразвукова тінь; 2 - кальцинат; 3 - сухожилки обертової манжети плеча); В. II - гіперехогенне вогнище 3 пониженою ультразвуковою тінню (1 - понижена ультразвукова тінь; 2 - кальцинати з неоднорідною структурою; 3 - сухожилки обертової манжети плеча); C. III - вогнище з пониженою гіперехогенністю без ультразвукової доріжки (1 - головка плечової кістки, відсутня ультразвукова тінь; 2 - нечіткі включення гідрооксиапатиту кальцію; 3 - сухожилки обертової манжети плеча).

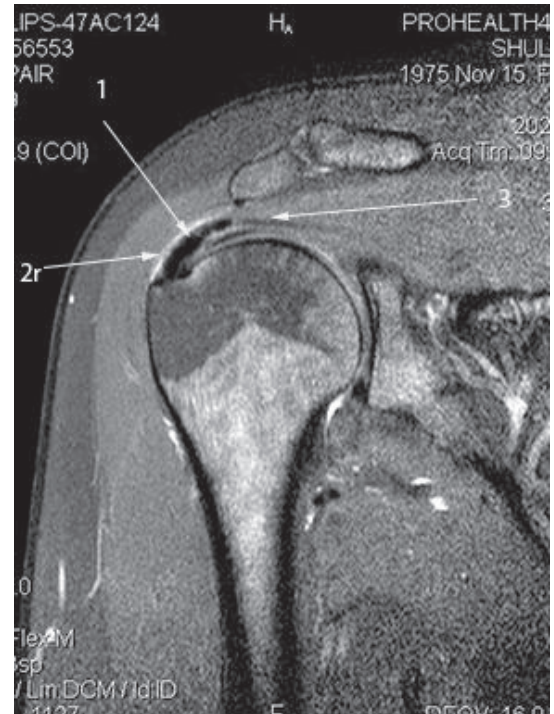

Рис. 4. МРТ-скан правого плечового суглоба: 1 - відкладення гідроксиапатиту кальцію в сухожилок надостьового м'яза; 2 - піддельтоподібна бурса; 3 - сухожилля надостьового м'яза.

На рентгенограмах та сонограмах визначалися сорормовані, щільні кальцинати з чіткою межею розміром менше 12 мм та мали чітко визначену ультразвукову доріжку. Таким пацієнтам ми призначали консервативне лікування. Воно включало нестероїдні протизапальні препарати, кріотерапію та лікувальну фрізкультура за Neer з метою усунення м'язового дисбалансу. В пацієнтів із хронічним перебігом, коли больовий синдром за шкалою ВАШ становив 3,87 бала, фукціональні розлади в плечовому суглобі були помірні й визначалися на рівні 64,67 бала, на рентгенограмах та сонограмах були сорормовані щільні кальцинати з чіткою межею розміром 15 мм та більше, з чітко визначеною ультразвуковою доріжкою застосовували одноразове промивання та аспірацію мас гідроксиапатиту під сонографрічним контролем (нідлінг) розчином місцевих анестетиків, з подальшим введенням глюкокортикостероїдів пролонгованої дії. Призначали нестероїдні протизапальні препарати, небензодіазепінові спазмолітики, кріотерапію та лікувальну фрізкультуру при зменшенні больового синдрому.

У пацієнтів із підгострим перебігом захворювання, коли больовий синдром становив $(5,84 \pm 0,21)$ бала, а фрукціональні розлади становили 52,45 бала, на рентгенограмах визначалися кальцинати з чіткою межею та неоднорідною структурою, а дані сонограорічного обстеження відповідали II типу. Проводилися промивання та аспірація мас гідроксиапатиту під сонографрічним контролем (нідлінг) з уведенням в кінці процедури пролонгованих глюкокортикоїдів (рис. 5). Після завершення процедури пацієнтам призначали знеболювальні, небензодіазепінові спазмолітики та кріотерапію.

У третій групі, коли пацієнти мали стійкий виражений больовий синдром за шкалою ВАШ $(7,81 \pm 0,23)$ бала, а фрункція плечового суглоба була різко обмежена до 14,58 бала відповідно до шкали Constant, первинно проводилася процедура промивання та аспірації гідроксиапатитних мас із обов'язковим введенням пролонгованих глюкокортикостероїдів. Частково їх водили і в піддельтоподібну бурсу. Призначалися нестероїдні протизапальні препарати, м'язові релаксанти центральної дії, кріотерапія. В частини пацієнтів застосовували 3 метою мобілізації косинкову пов'язку на 3-4 доби, з подальшим виконанням вправ лікувальної фрізкультури за Neer.

Усім пацієнтам рекомендували повторний огляд через 2 тижні та 1,5 місяця після первинної консультації та виконаних процедур.

Повторно звернулося 53 (71,62 \%) хворих. 3 групи пацієнтів, у яких кальцифікуючий тендиніт перебігав у хронічній фрормі - 17 (58,62 \%) осіб, з групи 3 підгострим перебігом - 26 (78,78 \%) та 10 (83,33 \%) пацієнтів із гострим перебігом захворювання. При повторному огляді проводилася оцінка больового 


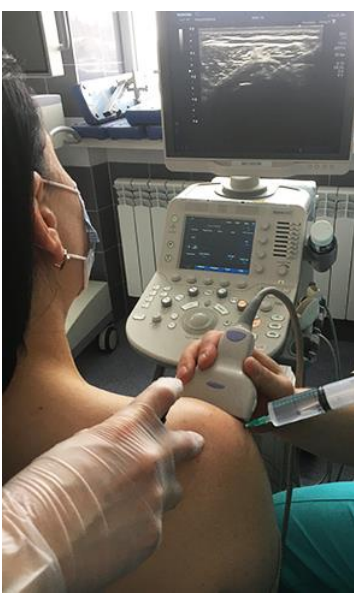

A

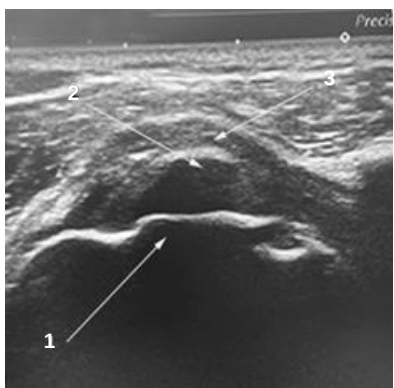

B

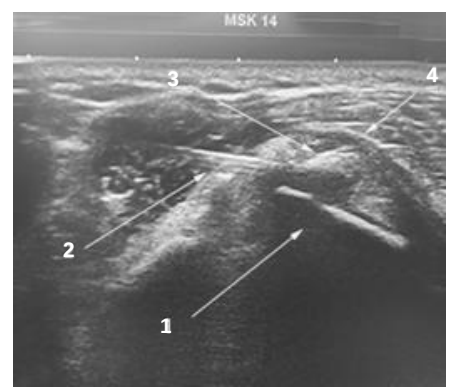

C

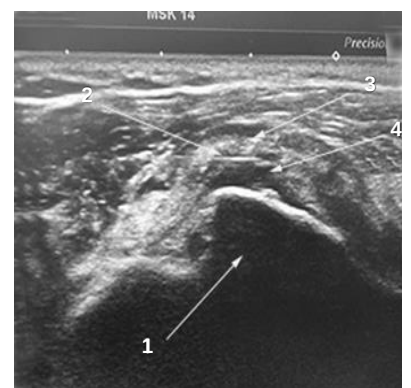

D

Рис. 5. А. Процедура промивання та аспірації мас гідроксиапатиту кальцію під сонографічним контролем (нідлінг); В. Сонограма плечового суглоба з наявністю гідроксиапатиту кальцію в обертовій манжеті плеча (1 - помірновиражена ультразвукова тінь; 2 - кальцинат; 3 - сухожилки обертової манжети плеча); С. Сонограма плечового суглоба підчас нідлінгу (1 - головка плечової кістки; 2 - голка з чіткою сонографрічною доріжкою; 3 - кальцинат; 4 - сухожилля обертової манжети плеча); D. Сонограма плечового суглоба підчас нідлінгу (1 - головка плечової кістки; 2 - голка з сонографічною доріжкою; 3 - сухожилля обертової манжети плеча; 4 - залишки мас гідроксиапатиту кальцію).

синдрому, вивчалася фрукціональна здатність плечового суглоба та виконувалося рентгенологічне та ультразвукове його дослідження.

У 33 (62,27 \%) пацієнтів через вказаний термін часу відмічалося клінічне та сонографрічне одужання. В групі пацієнтів, у яких кальцифрікуючий тендиноз мав хронічний перебіг, рівень больового синдрому був меншим 2 балів за шкалою ВАШ. Середні показники функції плечового суглоба становили 79,53 бала за шкалою Constant. У хворих із підгострим перебігом захворювання больовий синдром становив $(3,34 \pm 0,17)$ бала, а фукціональні розлади - 68,29 бала. Серед пацієнтів із гострим перебігом біль становив $(4,35 \pm 0,24)$ бала за шкалою ВАШ, фрукціональні розлади - 57,36 бала згідно зі шкалою Constant (рис. 6, 7). Рентгенологічно відмічалася картина, що нагадувала III тип кальцинатів, без чіткої межі з напівпрозорою структурою та ознаками кальцифрікованої касули. Сонографрічно визначалися розмиті нечіткі кальцифрікати без сонографічної доріжки.

У деяких випадках сонограсрічна картина відповідала помірновираженому піддельтоподібному бурситу. У зв'язку з тим, що у 20 (37,73 \%) пацієнтів утримувався больовий синдром та відмічалися фукціональні порушення в плечовому суглобі, проводилася повторна процедура нідлінгу.

Такі хворі були повторно оглянуті через 1,5 місяця. В процесі клінічного та рентгенологічного обстеження встановили, що покращення функції плечового суглоба зросло до 74,56 бала за шкалою Constant та визначався слабкістю м'язів плечового пояса та їх дисбалансом, больовий синдром становив 3,46 бала за шкалою ВАШ. Покращення стану хворих було встановлено у 9 (45\%) осіб.

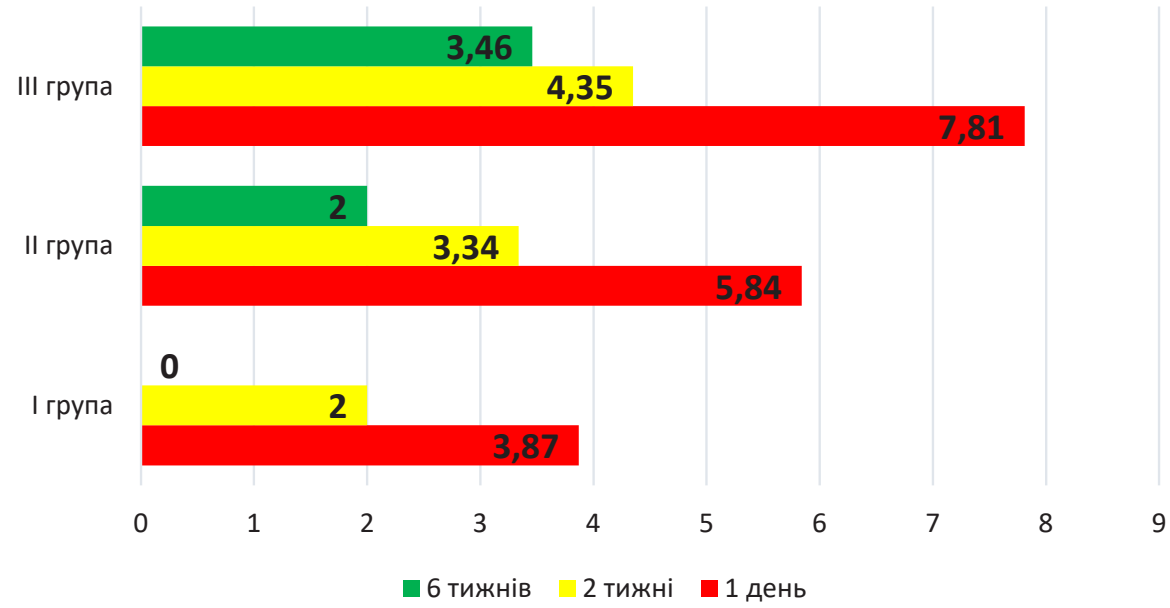

Рис. 6. Зміни вираження больового синдрому за шкалою ВАШ в клінічних групах пацієнтів у процесі лікування. 


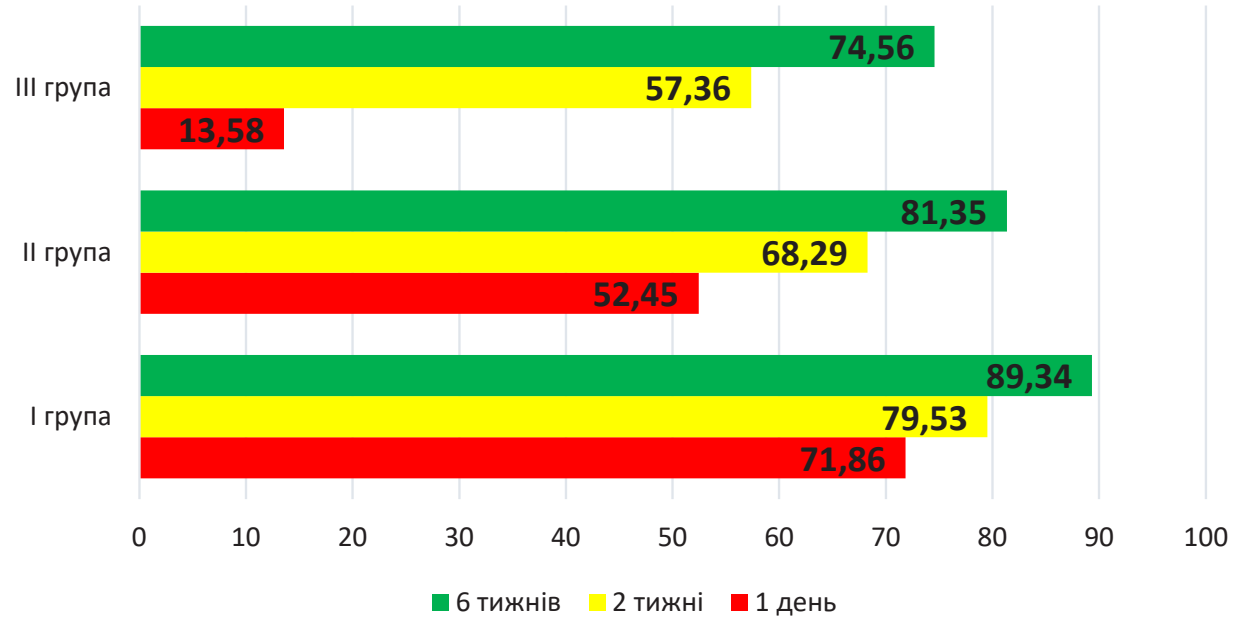

Рис. 7. Динаміка фууціональних змін у плечовому суглобі в клінічних групах пацієнтів за шкалою Constant у процесі лікування.

В 11 пацієнтів після проведеного курсу лікування ми не отримали позитивного результату. Провівши аналіз незадовільних результатів лікування та виконавши додаткові обстеження (МРТ), ми встановили, що їх причиною були наступні чинники: відкладення гідроксиапатиту розміром більше як 15 мм 3 товстою капсулою, що не дало змоги провести повноцінний нідлінг. Частковий дегенеративний розрив сухожилка надостьового м'яза, а також адгезивний капсуліт. У 10 (13,51 \%) випадках проведено оперативне втручання - видалення кальцинату та дегенеративно змінених волокон сухожилка надостьового та підостьового м'язів. Видалення кальцинату та ушивання часткового розриву обертової манжети плеча. Всі втручання проведено під артроскопічним контролем.

У перспективі буде вивчити віддаленні результати ефективності застосування нідлінгу з використанням пролонгованих глюкокортикоїдів у лікуванні

\section{СПИСОК ЛІТЕРАТУРИ}

1. De Palma A. F. Long-term study of shoulder joints affected with and treated for calcific tendinitis / A. F. De Palma, J. S. Kruper // Clin. Orthop. - 1961. - Vol. 20. P. 61-72. - Access mode : PMID: 13721957.

2. Constant C. R. A clinical method of functional assessment of the shoulder / C. R. Constant, A. H. Murley // Clin. Orthop. Relat. Res. - 1987. - Vol. 214. - P. 160-164. - Access mode : PMID: 3791738.

3. Calcific tendinitis of the shoulder / P. Diehl, L. Gerdesmeyer, H. Gollwitzer [et al.] // Orthopade. - 2011. - Vol. 40 (8). - P. 733-746. DOI: 10.1007/s00132-0111817-3.

4. Calcifying tendinitis of the shoulder: risk factors and effectiveness of physical therapy / M. E. FernándezCuadros, O. S. Pérez-Moro, J. Nieto-Blasco [et al.] // пацієнтів із кальцисрікуючим тендинітом обертової манжети плеча.

\section{ВИСНОВКИ}

Вибір лікувальної тактики повинен базуватися на анамнезі захворювання, характеристиці больового синдрому, функціональних розладах у плечовому суглобі та аналізі даних рентгенологічних та сонограсрічних обстежень, що дозволить визначити фразу перебігу захворювання.

Лікування повинно бути підібрано максимально індивідуально для кожного пацієнта з урахуванням фрази перебігу захворювання та включати при необхідності нестероїдні протизапальні препарати, небензодіазепінові спазмолітики, нідлінг з використанням місцевих анестетиків та пролонгованих глюкокортикоїдів, кріотерапію та лікувальну фрізкультуру.

Оперативна тактика в лікуванні кальцифрікуючого тендиніту є обмеженою. Ії доцільно застосовувати при чітко визначених показаннях.

Occup. Med. Health Aff. - 2015. - Vol. 3 (6). - P. 2. DOI: $10.4172 / 2329-6879.1000220$.

5. Functional results in calcific tendinitis of the shoulder treated with rehabilitation after ultrasonic-guided approach / I. Fusaro, S. Orsini, S. Diani [et al.] // Musculoskelet Surg. - 2011. - Vol. 95 (Suppl. 1). - P. S31-S36. DOI: 10.1007/ s12306-011-0119-6.

6. Gärtner J. Calcific tendinitis of the shoulder / J. Gärtner, A. Heyer // Orthopade. - 1995. - Vol. 24 (3). P. 284-302. - Access mode : PMID: 7617385.

7. Measures of adult pain: Visual Analog Scale for Pain (VAS Pain), Numeric Rating Scale for Pain (NRS Pain), McGill Pain Questionnaire (MPQ), Short-Form McGill Pain Questionnaire (SF-MPQ), Chronic Pain Grade Scale (CPGS), Short Form-36 Bodily Pain Scale (SF-36 BPS), 
and Measure of Intermittent and Constant Osteoarthritis Pain (ICOAP) / G. A. Hawker, S. Mian, T. Kendzerska, M. French // Arthritis Care Res. (Hoboken). - 2011. - Vol. 63 (Suppl. 11). - P. S 240-252. DOI: 10.1002/acr.20543.

8. Normalization of the Constant score / L. I. Katolik, A. A. Romeo, B. J. Cole [et al.] // J. Shoulder Elbow. Surg. - 2005. - Vol. 14 (3). - P. 279-285. DOI: 10.1016/j. jse.2004.10.009.

9. Ultrasound-guided needling combined with shockwave therapy for the treatment of calcifying tendonitis of the shoulder / C. Krasny, M. Enenkel, N. Aigner [et al.] // J. Bone J. Surg. Br. - 2005. - Vol. 87 (4). - P. 501-517. DOI: 10.1016/j.jse.2004.10.009.

10. Refior $\mathrm{H}$. Examinations of the pathology of the rotator cuff / H. Refior, A. Krödel, C. Melzer // Arch. Orthop. Trauma Surg. - 1987. - Vol. 106 (5). - P. 301-308. DOI: $10.1007 / B F 00454338$.

11. Rotator cuff calcific tendinitis: does warm saline solution improve the short-term outcome of double-needle
US-guided treatment? / L. M. Sconfienza, M. Bandirali, G. Serafini [et al.] // Radiology. - 2012. - Vol. 262 (2). P. 560-566. DOI: 10.1148/radiol.11111157.

12. Rotator cuff calcific tendonitis: shortterm and 10year outcomes after two-needle US-guided percutaneous treatment - nonrandomized controlled trial / G. Serafini, L. M. Sconfienza, F. Lacelli [et al.] // Radiology. - 2009. Vol. 252 (1). - P. 157-164. DOI: 10.1148/radiol.2521081816.

13. Speed C. A. Calcific tendinitis of the shoulder / C. A. Speed, B. L. Hazleman // N. Engl. J. Med. 1999. - Vol. 340(20). - P. 1582-1584. DOI: 10.1056/ NEJM199905203402011.

14. Uhthoff H. K. Calcific tendinopathy of the rotator cuff: pathogenesis, diagnosis and management / H. K. Uhthoff, J. W. Loehr // J. Am. Acad. Orthop. Surg. - 1997. Vol. 5 (4). - P. 183-191. DOI: 10.5435/00124635199707000-00001.

\section{REFERENCES}

1. De Palma AF, Kruper JS. Long-term study of shoulder joints affected with and treated for calcific tendinitis. Clin Orthop. 1961;20: 61-72. Available from: PMID: 13721957.

2. Constant CR, Murley AH. A clinical method of functional assessment of the shoulder. Clin Orthop Relat Res. 1987;(214): 160-4. Available from: PMID: 3791738.

3. Diehl P, Gerdesmeyer L, Gollwitzer H, Sauer W, Tischer T. Calcific tendinitis of the shoulder. Orthopade. 2011;40(8): 733-46. DOI: 10.1007/s00132-011-1817-3.

4. Fernández-Cuadros ME, Pérez-Moro OS, NietoBlasco J, Rivera-García V, Olazar-Pardeiro A. Calcifying tendinitis of the shoulder: risk factors and effectiveness of physical therapy. Occup Med Health Aff. 2015;3(6): 2. Available from: https://doi.org/10.4172/2329-6879.1000220.

5. Fusaro I, Orsini S, Diani S, Saffioti G, Zaccarelli L, Galletti S. Functional results in calcific tendinitis of the shoulder treated with rehabilitation after ultrasonic-guided approach. Musculoskelet Surg. 2011;95(Suppl.1): S31-S36. DOI: $10.4172 / 2329-6879.1000220$.

6. Gärtner J, Heyer A. Calcific tendinitis of the shoulder. Orthopade. 1995;24(3): 284-302. DOI: 10.1007/s12306011-0119-6.

7. Hawker GA, Mian S, Kendzerska T, French M. Measures of adult pain: visual analog scale for pain (VAS Pain), numeric rating scale for pain (NRS Pain), McGill Pain Questionnaire (MPQ), Short-Form McGill Pain Questionnaire (SF-MPQ), Chronic Pain Grade Scale (CPGS), Short Form-36 Bodily Pain Scale (SF-36 BPS), and Measure of Intermittent and Constant Osteoarthritis Pain (ICOAP). Arthritis Care Res (Hoboken). 2011;63(Suppl.11): 240-52. Available from: PMID: 7617385.
8. Katolik LI, Romeo AA, Cole BJ, Verma NN, Hayden JK, Bach BR. Normalization of the Constant score. J Shoulder Elbow Surg. 2005;14(3): 279-85. DOI:10.1016/j. jse.2004.10.009.

9. Krasny C, Enenkel M, Aigner N, Wlk M, Landsiedl F. Ultrasound-guided needling combined with shockwave therapy for the treatment of calcifying tendonitis of the shoulder. J Bone J Surg Br. 2005;87(4): 501-17. DOI:10.1016/j.jse.2004.10.009.

10. Refior $\mathrm{H}$, Krödel A, Melzer $\mathrm{C}$. Examinations of the pathology of the rotator cuff. Arch Orthop Trauma Surg. 1987;106(5): 301-8. DOI: 10.1007/BF00454338.

11. Sconfienza LM, Bandirali M, Serafini G, Lacelli F, Aliprandi A, Di Leo G, Sardanelli F. Rotator cuff calcific tendinitis: does warm saline solution improve the short-term outcome of double-needle US-guided treatment? Radiology. 2012;262(2): 560-6. DOI:10.1148/radiol.11111157.

12. Serafini G, Sconfienza LM, Lacelli F, Silvestri E, Aliprandi A, Sardanelli F. Rotator cuff calcific tendonitis: shortterm and 10-year outcomes after two-needle USguided percutaneous treatment-nonrandomized controlled trial. Radiology. 2009;252(1): 157-64. DOI:10.1148/ radiol.2521081816.

13. Speed CA, Hazleman BL. Calcific tendinitis of the shoulder. N Engl J Med. 1999;340(20): 1582-4. DOI: 10.1056/NEJM199905203402011.

14. Uhthoff HK, Loehr JW. Calcific tendinopathy of the rotator cuff: pathogenesis, diagnosis and management. J Am Acad Orthop Surg. 1997;5(4): 183-91. DOI :10.5435/00124635-199707000-00001. 